\title{
The Socio-Economic Conditions of Caretaker Families Living in Uncompleted Houses in the Awutu-Senya East Municipality, Ghana
}

\author{
Charles Peprah ${ }^{1}$, Eric Oduro-Ofori ${ }^{1} \&$ Isaac Asante-Wusu ${ }^{1}$ \\ ${ }^{1}$ Department of Planning, Kwame Nkrumah University of Science \& Technology, Kumasi, Ghana \\ Correspondence: Charles Peprah, Department of Planning, Kwame Nkrumah University of Science \& \\ Technology, Kumasi, Ghana. E-mail: akwes2002@yahoo.com
}

\author{
Received: March 5, 2015 Accepted: March 12, 2015 Online Published: May 28, 2015 \\ doi:10.5539/jsd.v8n3p309 URL: http://dx.doi.org/10.5539/jsd.v8n3p309
}

\begin{abstract}
Although housing is a fundamental human need, many lower income earning groups the world over continue to live in poor housing structures. Due to continuous urbanization in Ghana without a corresponding increase in decent or affordable rental housing, many urban dwellers are compelled to live in uncompleted housing units. Despite the increasing number of caretaker families residing in uncompleted houses in Ghana, there exists little or no well documented evidence of their plights. Consequently, this study was undertaken to assess the socio-economic conditions of families living in uncompleted houses as caretakers in the Awutu-Senya East Municipality of Ghana. The study revealed that about $56 \%$ of the sampled respondents earned between GH $\phi 100$ and $\mathrm{GH} \phi 200$ as monthly incomes, while 27\% earned between GHф201 and GH $\phi 400$. It was realised that about 39 percent used torch lights for lightening, 31 percent used kerosene lamps and 8 percent used electricity. It was also observed that overcrowding was pervasive among respondents where about 85 percent with a family size of between three and four occupied just a single room while 15 percent with a family size of five or more dwelled in two rooms. In spite of the high overcrowding among respondents, 58 percent had lived in uncompleted houses for more than six (6) years while 42 percent had been occupying uncompleted houses between three and five years in the Municipality. To reduce the incidence of increasing habitation of uncompleted houses in the Municipality, a well-defined and comprehensive integrated system of housing finance should be instituted to enable low income earning households own decent but affordable housing, while pro-poor alternative strategies to mortgage financing arrangements are formulated.
\end{abstract}

Keywords: Awutu-Senya East Municipality, caretaker families, Ghana, uncompleted houses

\section{Introduction}

Housing represents one of the most important necessities of life for which all persons require for safe survival (Ghai, 2002; Adedeji, 2004)). Consequently, the need to enhance access to a reduced cost of decent housing has been brought to bear in literature. Wardrip, Williams \& Hague, (2011) maintain that expenditure in housing by households should not deprive them from the opportunity of getting access to other equally essentials such as healthier diets, quality education to children, good healthcare, among others. As a result, policy makers all over the world have been interested in providing adequate housing to meet the needs of mankind. However, the re-current nature of housing needs and the unending desire for good housing tend to confirm the widely held view that there is hardly any society that has successfully met the housing requirements of their inhabitants (Modupe, 1986).

Quality urban housing development is deemed essential in delivering good quality of life, in meeting citizens' needs and in achieving other aspects of government policy in relation to sustainable communities, housing, planning, sustainable transport, energy efficiency and environmental quality (DEHLG, 2010). Additionally, since housing is a durable commodity the ability of households to access housing units in an adequate and decent environment without compromising other essential needs has greater economic benefits for different actors in an economy (Wood, 2004). Consequently, the focus of various governments the world over is to adopt comprehensive strategies aimed at meeting the housing needs of low income earners who are bedeviled with financial limitations to acquire a decent housing in a decent environment (Vuluku and Gachanja, 2014).

Although the poor are normally cited as the occupants of poor housing the world over, evidence abounds that living in poor housing has a significant financial burden than decent housing. As observed by Duncan (2005), 
poor housing conditions compromise the ability to adequately afford the expenditure for food, health and education of children while it limits income generation of families. The livelihoods of families are thus affected, and hence trap them in vicious cycle of poverty due to the money and time spent on housing costs. According to Ellis (2000) livelihood represents "the activities, the assets and the access that jointly determine the living gained by the individual or household"; while Chambers and Conway (1992) maintain that a livelihood comprises people, their capabilities and their means of living, including food, income and assets. However, due to the problem of access to essential facilities such as clean water, clean air and improved sanitation in substandard housing, acute diseases, injury, child burns, child mortality and deaths are very high among occupants, and thus affect their means of living (Badasu, 2004).

The significance of providing quality and adequate housing in any country to its citizens cannot be underestimated. However, despite the recognition of housing as a fundamental need of humanity, many lower income earning groups the world over continue to live in poor housing structures due to the high cost associated with access to decent housing. Due to the high cost associated with housing prices as well as rent, it is estimated that the average households in many parts of the world spend about one third of their monthly incomes on housing expenditures, while poor households devote almost half of their incomes to housing, and thus affect non-housing consumption and household well-being (Quigley and Raphael, 2004). Research evidence indicates that millions of homeless men, women and children continue to live in the streets of both the developed and developing countries. However, the problem keep worsening as more than a million people are born in or move to cities in the developing world, driving up the need for new and better housing (PACO and IHC, 2006).

Housing shortage is one of the most critical socio-economic challenges facing Ghana as a country (National Development Planning Commission [NDPC] 2008). In Ghana, it is estimated that about 85000 housing units are needed annually to address the housing deficit over the next 20 years (Minister of Water Resource, Works and Housing [MWRWH], 2014). However, Ahadzie and Amoah-Mensah (2010) maintain that about 1.2 million housing units would be needed to bridge the gap by the end of the next decade. In spite of the fact that Ghana is making efforts to solve the housing crisis and to overcome the persistent deficit in housing delivery, there is still housing deficit (Clottey, 2007). Due to inability of successive governments to provide adequate housing to all through comprehensive housing programmes, a section of the populace continue to settle in uncompleted houses, especially in the major cities in the quest to prevent homelessness due to poverty (National Development Planning Commission [NDPC], 2010). The cost of housing in urban areas, coupled with cumbersome accessibility to mortgage loans and inadequate government programmes on comprehensive housing delivery system have made low income earners to find havens in substandard housing and unhealthy conditions (Bank of Ghana [BoG], 2007).

As population increases, more housing is needed to offset the backlog created by the rapidly growing need of mankind. In Ghana, rapid increases in population and urbanization coupled with the inability of the housing delivery system to meet the growing demand have created strains in the existing housing stock and infrastructure in most urban areas. As observed by Badasu (2013), the gap between housing demand and supply of housing is a primary factor of governments' inability to adequately provide the housing need of the growing and urbanized population. However, the situation is not likely to change since the high rate of population growth as a result of natural increase and rural urban drift coupled with other factors have outstripped the rate of housing development and service provision (Kumasi Metropolitan Assembly [KMA] (2010), hence compelling families to live in uncompleted houses. Despite the fact that uncompleted houses provide some sort of shelter to families who are unable to secure regular accommodation, research evidence articulates that living in uncompleted buildings often poses significant risks on health and well-being as families living in uncompleted houses mostly depend on the public or neighbours for access to essential services including water and sanitation. However, information on the number of people living in uncompleted buildings is limited since inhabitants are often inadequately covered by formal censuses and mostly neglected when it comes to formulating housing policies (Duncan, 2005). For this reason, there is a need to enumerate the number of families living in uncompleted dwellings in Ghana for better housing policies.

\section{The Study Municipality}

The Awutu Senya East Municipal Assembly (ASEMA) is a newly created Municipality that was carved out of the former Awutu Senya District in 2012 and established as a Municipality by Legislative Instrument (LI) 2025. The Awutu Senya East Municipal is located in the Eastern part of the Central Region within latitudes $5^{\circ} 45^{\circ}$ south and $6^{\circ} 00^{\circ}$ north and from Longitude $0^{\circ} 20$ west to $0^{\circ} 35$ East. It shares common boundaries with Ga South Municipal Assembly (in the Greater Accra Region) in the East, Awutu Senya West District in the North and Gomoa East District in the West and South respectively. The Municipality covers a total land area of about 180 
sq $\mathrm{km}$, which is about $1.8 \%$ of the total area of the Central Region. Kasoa, the Municipal Capital is located at the south-easting part, about $31 \mathrm{~km}$ from the national capital Accra. (See figures 1 and 2)

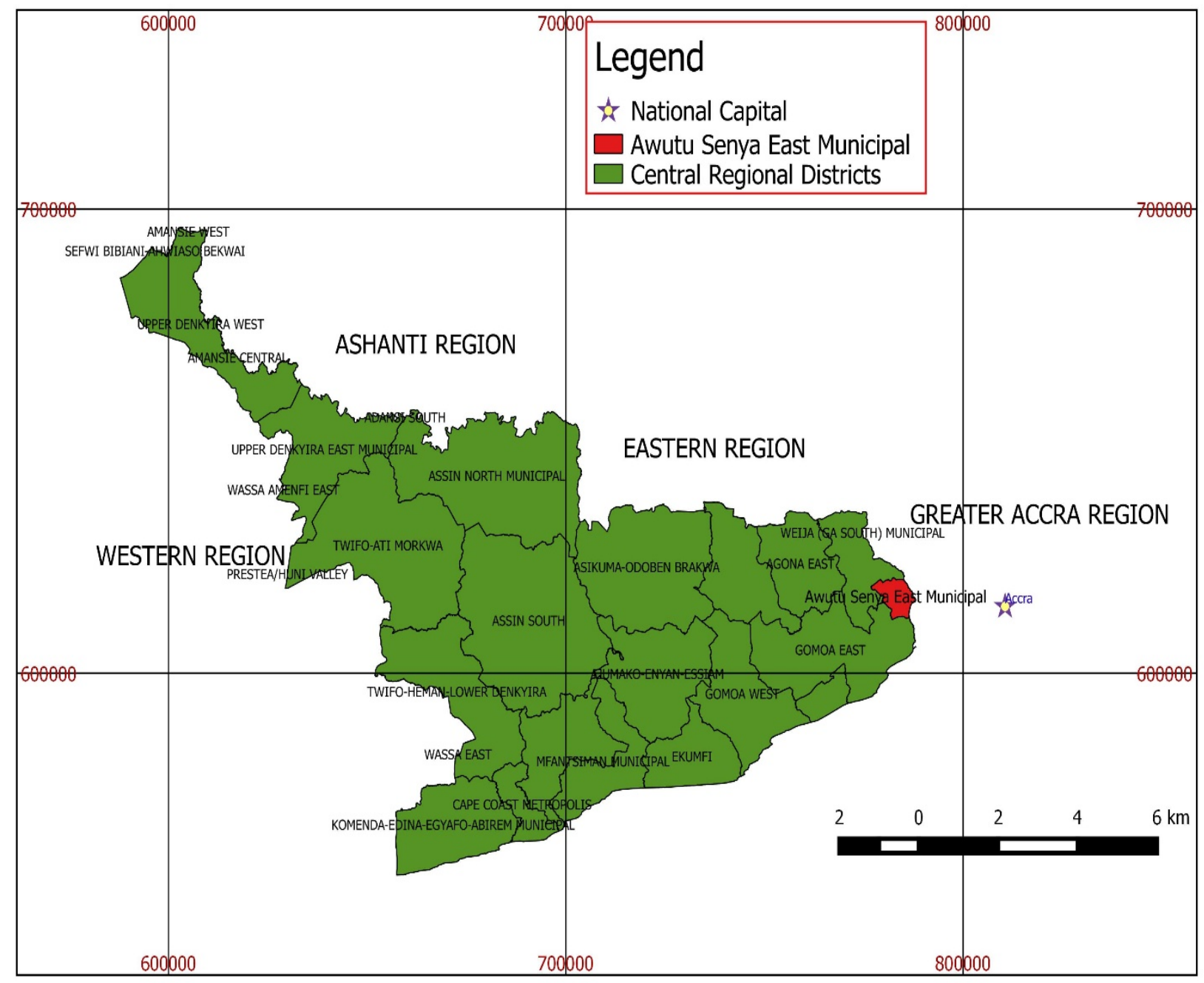

Figure 1. Awutu-Senya East Municipality in regional context 


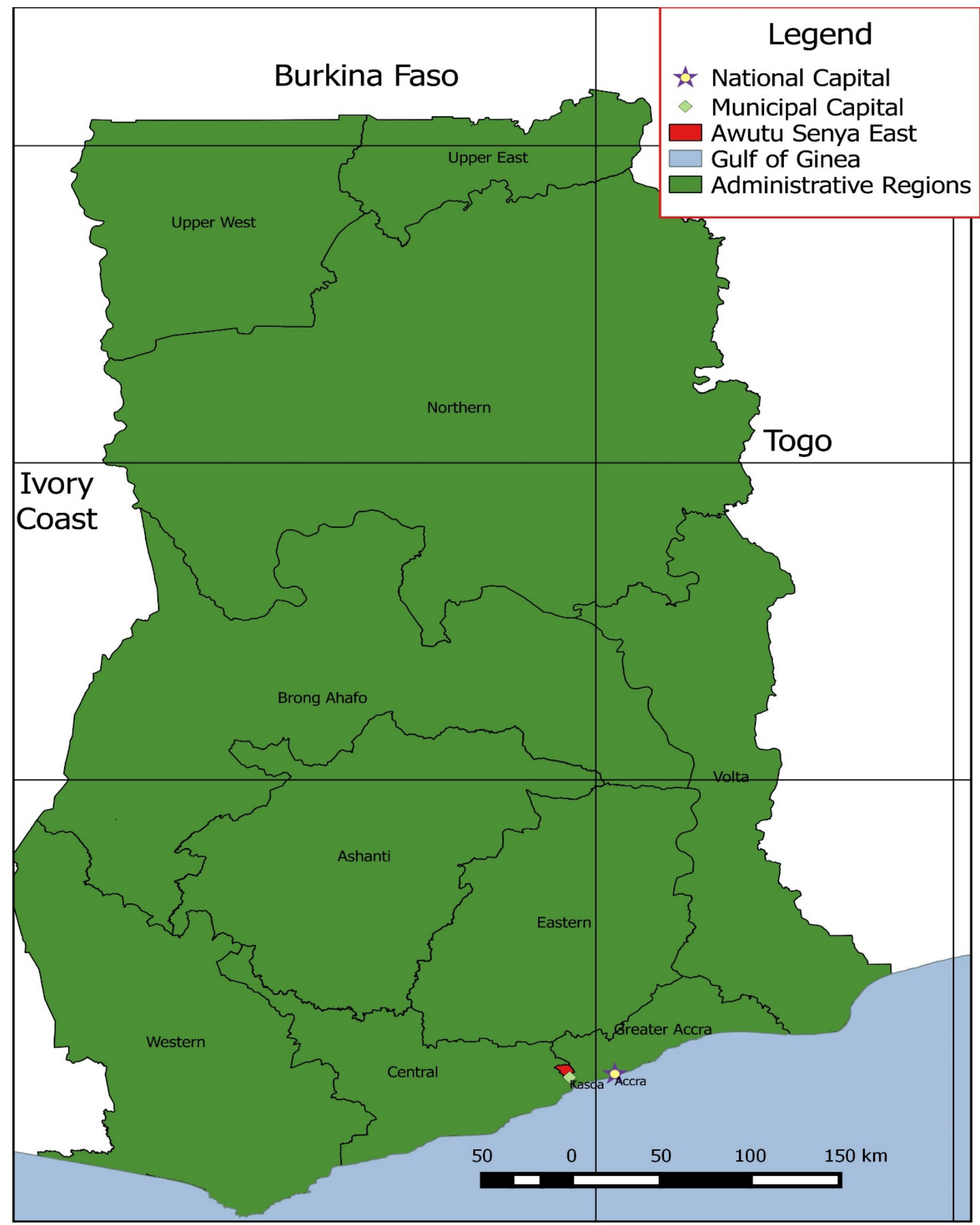

Figure 2. Awutu-Senya East in national context

The Awutu-Senya East Municipality is one of the sprawling Municipalities in Ghana giving cognizance of its proximity to the national capital, Accra. A Municipality that had hitherto been dormant has now become the abode for all manner of people. Due to increased merchandize activities in the Municipality a lot of people have found it convenient to settle there so as to take advantage of the economic prospects it offers (Awutu-Senya East 
Municipal Assembly [ASEMA], 2013). This has created a number of development challenges including housing within the sprawling Municipality. Consequently, low income earners and new immigrants have resorted to dwelling in uncompleted housings with the core 'mandates' of being caretakers without recourse to the associated challenges thereof. Consequently, this research paper seeks to analyse the socio-economic conditions of caretaker families living in uncompleted houses in the Municipality.

\section{Brief Perspective on the Concept of Housing}

The development of housing theory has undergone series of debate over the years. According to Turner (1976), housing could be looked at in two ways: housing as a noun and housing as a verb. While the former typically refers to the existence of a physical structure, and thus views housing as a product or commodity; the latter focuses on the universal activity/on-going processes that lead to the production of a physical structure for habitation. Housing is indisputably a broad subject, and thus has generated an immense body of research among experts the world over. For this reason, housing has been defined differently by different authors and authorities at different locations and time period. While some view housing as protective structures that guard individuals against danger, others argue that housing goes beyond just giving protection to incorporating the ancillary facilities that provide comfort for safe living.

As advanced by the United Nations Human Settlement Programme, (2011) housing is a structurally separate and independent place of abode which has the potency of isolating a person or group of persons from the hazards of climate such as storms and the sun. This definition therefore, conceptualizes housing as a physical structure which provides protection to humanity against climatic weather conditions. However, Aribigbola, (2001) maintains that, housing entails a broad spectrum of environmental factors such as good access routes, ventilation, sanitation and access to basic human needs such as water that make living acceptable and comfortable, and not just the mere existence of a static structure for the protection of mankind. Moreover, housing is a multidimensional commodity that encompasses physical shelter, the related services and the inputs such as land and finance required to produce and maintained it (Ministry of Local Government and Rural Development [MLGRD], 2010). Additionally, the Ghana Statistical Service [GSS], (2012) views housing as any type of shelter whether separate houses, semi-detached houses, flats/apartments, compound houses, huts, tents, kiosks, containers, or uncompleted which has the potency of providing protection to humanity against climatic weather conditions.

On the grounds of it essence to human existence, housing is viewed as a social wage. According to the Swadish Cooperative Centre [SCC] (2005), housing is a crucial commodity and that housing deficit represents an unjust distribution of societal wealth. Consequently, housing is deemed a basic human need that is required by all for survival. As a result of the pressing nature of housing to human existence, international advocacy institutions have over the years, placed much emphasis on housing as a fundamental human right which needs to be enjoyed by all regardless of one's income level. During the Cocoyoc declaration of 1974, development was redefined to centre on human beings, with greater emphasis on shelter/housing as a basic human need. For this reason, it is maintained that any process of growth that does not lead to its fulfilment of decently housing humanity is considered as a travesty to the idea of development since a decent housing is a necessity for good health as well as social, political and economic development (Ghai, 2002). Not only does housing serve as a critical resource for human security, it is also a commodity that is needed for the performance of daily domestic tasks.

\subsection{Uncompleted Housing Units Habitation in Ghana}

Uncompleted housing units are houses that are not up-to-standard and have some of the construction works left for completion; and thus usually lack certain basic facilities such as water, electricity, among others deemed critical for survival (Owusu and Asamoah, 2005). Generally, reliable and accurate information about residents living in uncompleted houses in Ghana is lacking. As observed by Duncan, (2005), information on the number of people living in uncompleted buildings in Ghana is often limited since inhabitants are not inadequately covered by formal censuses and mostly neglected when housing policies are formulated. The Swadish Cooperative Centre [SCC], (2005) however asserts that, there is paucity of secondary information on occupants of uncompleted houses in Ghana due to the fact that the situation is a new development in the country. Despite the fact that little or no information is known in literature about the number of caretaker families living in uncompleted housing units in Ghana, the Ghana Statistical Service (2012) posits that about 94,913 people in Ghana live in uncompleted houses, representing about 1.6 percent of the total dwelling types in the country. Figure 3 depicts the number of inhabitants living in uncompleted buildings on regional bases. 


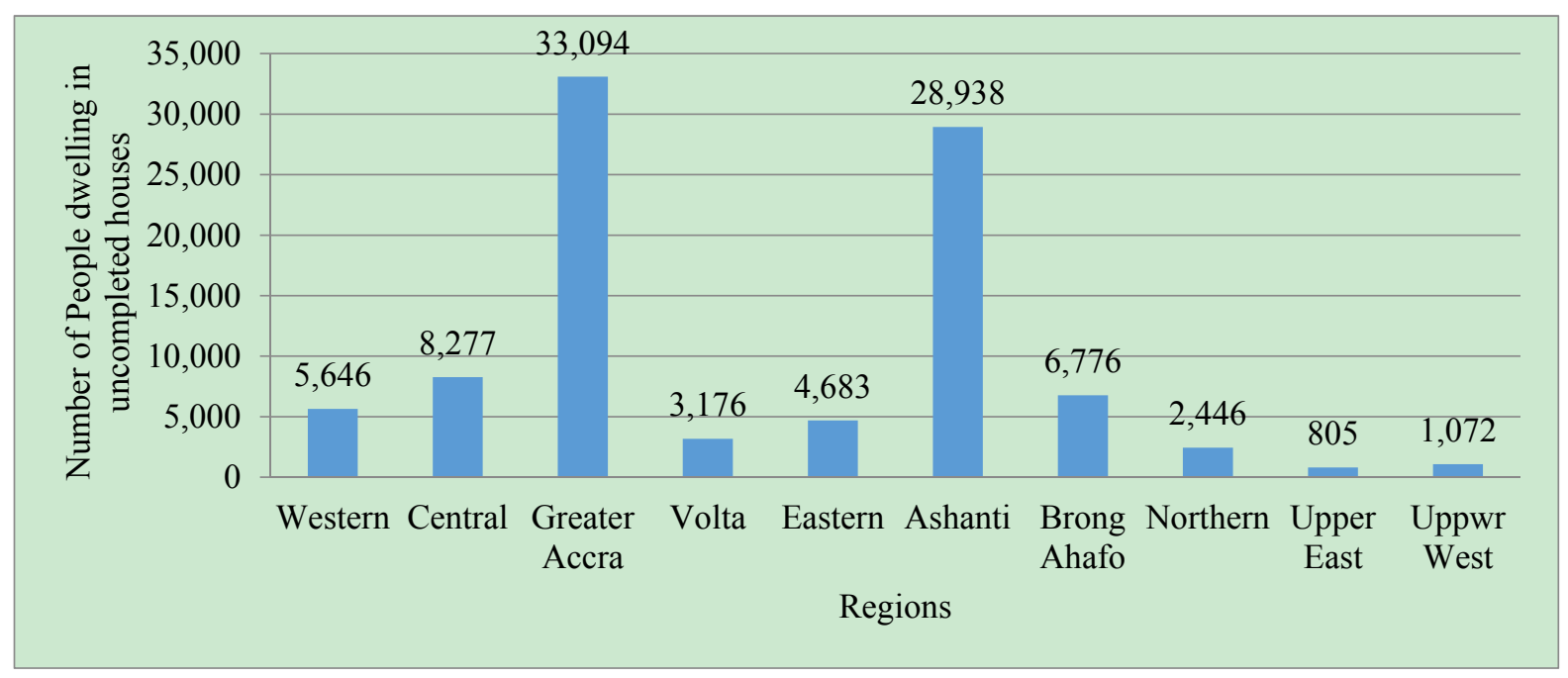

Figure 3. Regional distribution of dwellers in uncompleted houses

Source: GSS, 2012 (2010 Population and Housing Census, summary report)

The Figure 3 illustrates the regional distribution of people dwelling in uncompleted houses in Ghana. On regional bases 33,094 of the total households (94913) living in uncompleted residential housing in the country live in Greater Accra while 28,938 of the households who live in uncompleted residential housings are located in the Ashanti Region. The Central Region however, within which the study Municipality is found is the next Region after the Greater Accra and the Ashanti Regions of the increased number of households residing in uncompleted houses in Ghana. This could be attributed to the rapid urbanisation of some of the region's districts such as the Awutu-Senya East Municipality, and thus forcing immigrants to find shelter in uncompleted houses (Ghana Statistical Service [GSS], 2012).

\section{Methodology}

The methodology adopted comprises a combination of qualitative and quantitative techniques of data gathering and analysis. This was premised on the fact that combining both the quantitative and qualitative techniques of data analysis in a research helps to balance the strengths and weaknesses of the two, while it aids in achieving a greater degree of validity and reliability (Medina, 1998).

The study employed stratified and simple random methods of sampling to interview 145 caretaker families living in uncompleted houses within the Municipality as well as other key informants between November, 2014 and January, 2015. Among the key informants that were a purposively sampled and interviewed included one Real Estate Company, a Development Planning and Policy Officer, a Water Tanker Operator, a Landlord as well as a Physical Planning officer and a Municipal Works Engineer within the Municipal Assembly. Both closed and open-ended questionnaires were used by the researchers to interview respondents. Among the key topics of the interview were the Socio-economic characters of caretaker families; housing conditions and types; duration of stay; housing services; and infrastructure, among others.

The analysis of the quantitative data began with a rationalization using the Statistical Programme for Social Sciences (SPSS), version 18, and Microsoft Excel. The rationalized data were used to generate measures of central tendencies for the analysis. The policy implications of the statistics generated by the SPSS and the Microsoft Excel were made by the researcher after carefully studying the data. The analysis of the qualitative data involved making comprehensive statements and analytical descriptions about the statements made by the respondents during the data collection exercise. Conditions of caretaker families in the Municipality were measured by using but not limited to household income; occupation; and access to facilities such as water supply and electricity.

\section{Research Results and Discussions}

\subsection{Employment Status of Respondents}

Employment status of a family the world over undoubtedly determines the ability of individuals to make a living. Decent and well-paid jobs enable individuals to afford accommodation rents, and thus reduce the incidence of 
seeking shelter in substandard housing structures (Ghana Statistical Service, 2012). In the Awutu-Senya East Municipality, despite the fact that virtually all the caretaker families living in uncompleted houses were employed in one sector or another, their meagre salaries and, or low profit returns from their economic activities rendered them incapable to either afford 'self- owned' accommodation or decent rental housing. From the research results, 92 percent of respondents were employed while 8 percent were unemployed. About 88 percent of the employed respondents were in the informal sector (including driving, petty trading barbering, seamstress, hair dressing and masonry) while the reaming 4 percent were formal sector employers (mostly teachers). Though majority of the caretaker families living in uncompleted houses in the Awutu-Senya East Municipality were employed but in the informal sector, they were mostly denied the opportunities of making choices regarding the kinds of housing units they wished to occupy, and thus rendered them poor. As observed by the United Nation Development Programme[UNDP], (2006) a person is said to be poor when he/she is denied the opportunities and choices most basic to human development to lead a long, healthy, creative life and to enjoy a decent standard of living, freedom, dignity, self-esteem and the respect of others.

Undoubtedly, a person's monthly income or the financial position of a people is a crucial determinant of the kind of housing unit they could afford and choose to occupy. In analysing the economic conditions of persons living in caretaker housing units in the Awutu-Senya East Municipality, the research results revealed that about $56 \%$ of the sampled respondents earned between $\mathrm{GH} \not 100$ and $\mathrm{GH} \not 200$ as monthly incomes, $27 \%$ earned between GH $₫ 201$ and GHc400 monthly while 8 percent earned between GH $₫ 401$ and $\mathrm{GH} \phi 500$ as shown in figure 4 . Notwithstanding the fact that about $9 \%$ of the sampled respondents earned between $\mathrm{GH} \phi 501$ and $\mathrm{GH} \notin 700$, close to 77 percent of such respondents $(76.9 \%)$ were formal sector workers while 23 percent were 'self-employed persons within the informal sector.

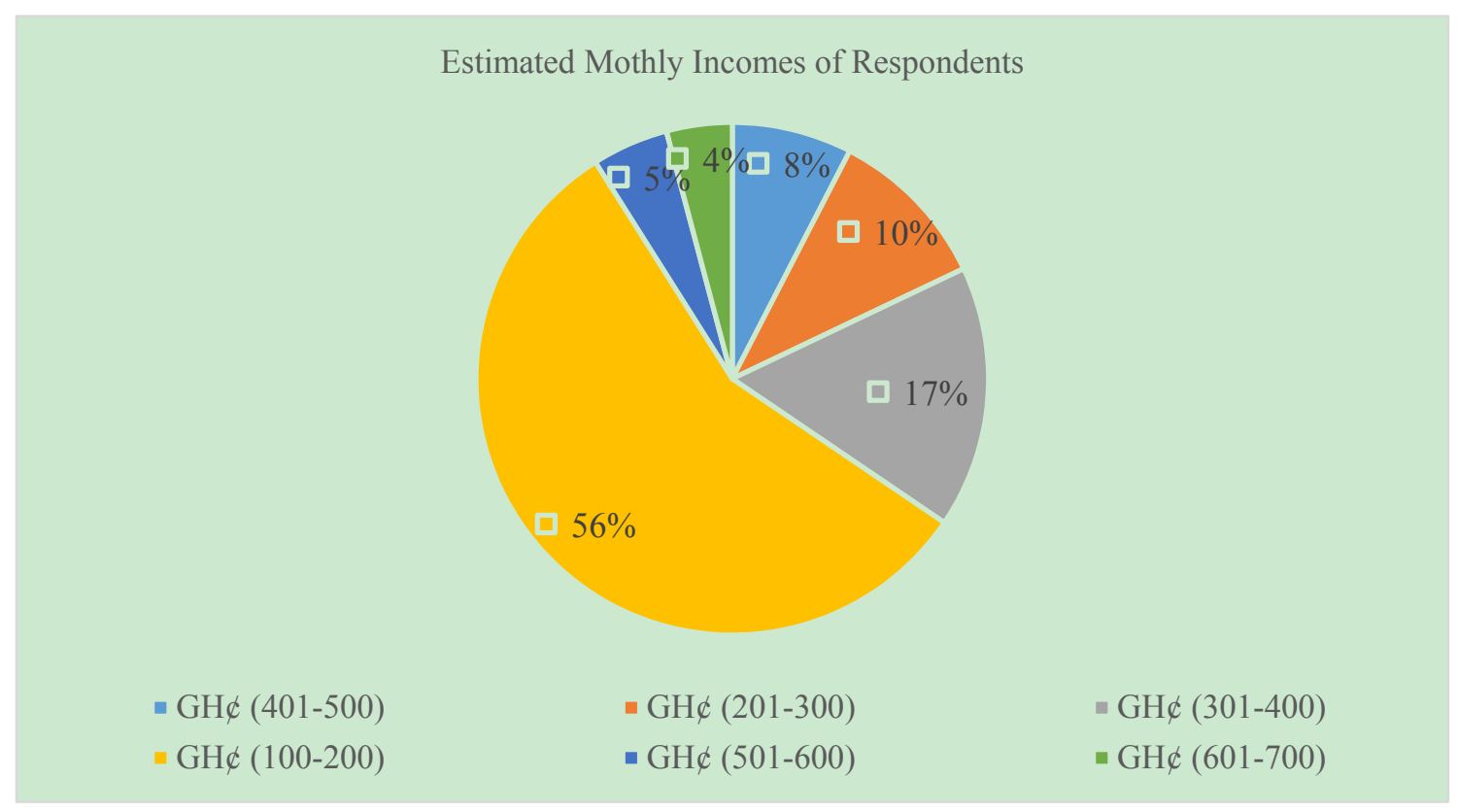

Figure 4. Income distribution of caretaker families

Source: Authors' Construct, January 2015

Housing affordability has been a universal challenge for low-income households. Consequently, lack of low-cost housing option in the Awutu-Senya East Municipality has undermined the quality of life for caretaker families living in uncompleted houses, and thus forcing difficult tradeoffs in housing quality and spending on other vital needs. As observed by the American Joint Centre for Housing Studies (2011), a household is said to be burdened if more than $30 \%$ of the household's monthly income is spent on housing costs, and that lower-income earning households the world over are more likely to live in structurally deficient housing, as compared to a higher income earning households. It is therefore of no surprise that the habitation of uncompleted houses in the Awutu-Senya East Municipality has become an emerging development since the quest to afford a decent housing will necessarily warrant compromising other vital needs required for survival, especially, where Ghana's existing 
Rent Act of 1963 is not well enforced.

\subsection{Types of Dwelling Units Occupied by Respondents}

In Ghana the types of dwelling units differ considerably from one residential area to another. Hence, the higher the level of income of an area, the better the dwelling types all things being equal. Although the Awutu-Senya East Municipality is a newly but rapidly growing Municipality in Ghana, it serves as abode for different categories of income groups (low, middle and higher). In the analysis of the type of housing, it was established that while about $67 \%$ of the sampled caretaker families resided in separate (detached) uncompleted housing units entrusted to their care for safeguards until final completion, $22 \%$ and $11 \%$ dwelled in compound and semi-detached houses respectively in the Awutu-Senya East Municipality. The revelation is however in contravention with the national data where majority of households $(51.3 \%)$ and 51.5 percent resided in compound houses in the Central Region and at the national level respectively. Additionally, the research results also defied the existing situation in the study Municipality where about 52.1 percent of the total households lived in compound houses. The situation is however explained from the fact that most of the uncompleted houses respondents occupied were owned by high and middle income earning classes, especially at the periphery of the sprawling Municipality, but they had entrusted such houses to the care of respondents until their completion. Plates 1 and 2 depict some of the uncompleted houses respondents occupied in the Municipality.

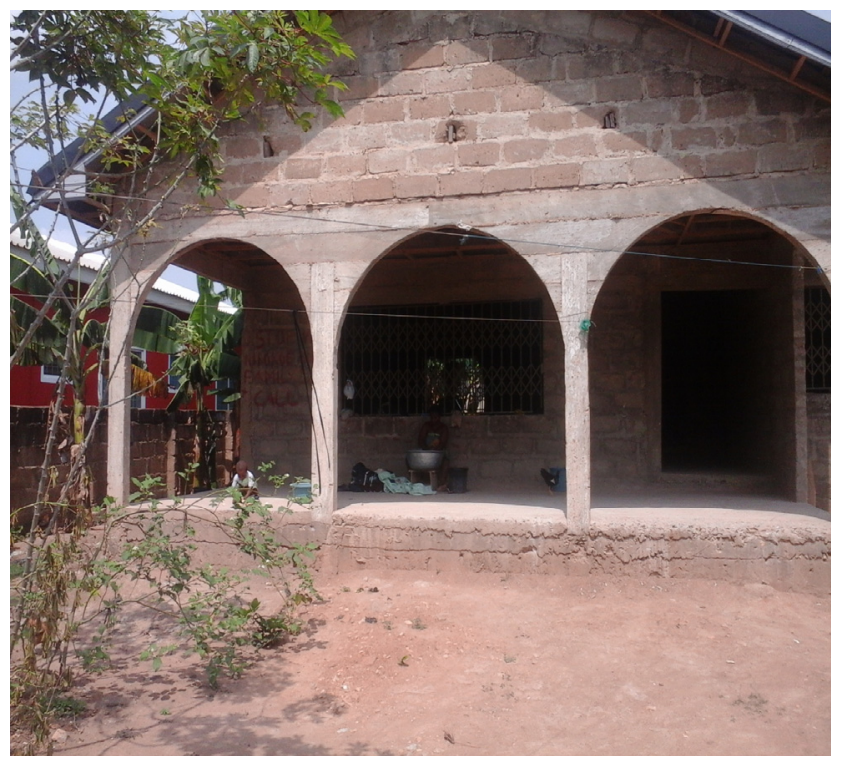

Plate 1. Uncompleted semi-detached house

Source: Field Survey, January 2015

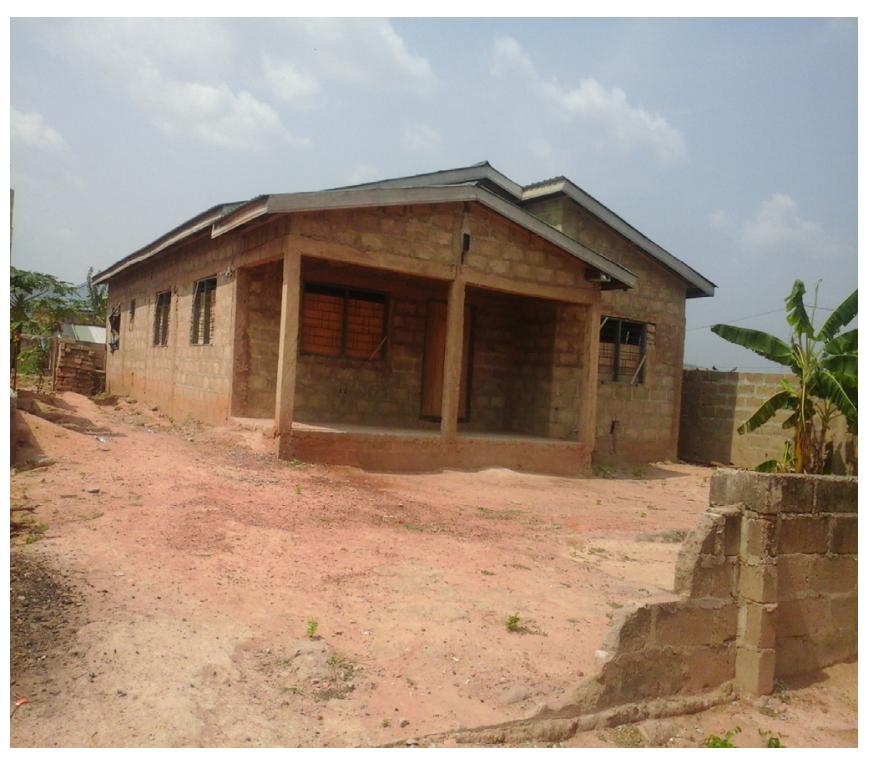

Plate 2. Uncompleted detached house

\subsection{Room Occupancy}

The number of rooms a household occupies is one of the best indicators for assessing how crowded the dwelling unit is. Overcrowding is one of the fastest ways through which communicable diseases spread easily among a group of people residing in a common room. As maintained by Wilkinson (1999), overcrowding increases vulnerability to airborne infections such as $\mathrm{TB}$, and other enteric diseases such as diarrhoea are often more frequent in overcrowded houses. Additionally, poor housing conditions such as poor ventilation as a result of overcrowding in rooms and pest infestation can increase mites and other allergens associated with poor health (Robert Wood Johnson Foundation, 2008). As a result, various attempts have been made by both national and international authorities to address inadequate housing units and its concomitant problems, especially in developing countries where housing deficit is eminent (Angel, 2000).

The research results on the room occupancy among the sampled respondents revealed that more than two-thirds (85 percent) of caretaker families with a family size of between three and four in the study Municipality occupied just a single room while 15 percent with a family size of five or more dwelled in two rooms. This situation is however in contrast with the prevailing development in the Central Region and at the national level where about 54.5 percent and 44.5 percent occupy single rooms respectively. Not only does this indicates a mark 
of high room occupancy rate among caretaker families living in uncompleted houses in the Municipality, or is it a deviation from the Regional and the National figures, but it is a situation that has dire consequences on the health and personal development of the individual family members involved (Robert Wood Johnson Foundation, 2008). Among the health implications room overcrowding could cause are psychological distress; lack of tolerance, reduced levels of concentration and mental health (Ghana Statistical Service, 2012). Interestingly, more than half $(58.4 \%)$ of the respondents had lived in uncompleted houses for more than six (6) years while 21 percent and 20.6 percent had been occupying uncompleted houses in the Municipality for three years and five years respectively. However, over 86 percent of the respondents had to evacuate their old houses of abode upon completion of those houses to seek for shelter in similar housing units within the Municipality. Thus, not only are caretaker families living in uncompleted houses in the study Municipality have their health endangered, but also are vulnerable to eviction whenever the uncompleted houses they occupy are completed for habitation by the 'rightful owners'

\subsection{Access to Essential Household Facilities}

Accessibility to essential facilities amenities such as water and sanitation, electricity, inter alia, are deemed very crucial in any housing unit since it enhances good living condition. As maintained by Giddings (2007), poor housing living conditions directly affect the productivity of the labor force, efficiency, quality of life, health and competitiveness of cities with dire consequences on economic growth of any country. In analysing the socio-economic condition of caretaker families living in the Awutu-Senya East Municipality, therefore, access to crucial facilities including water and sanitation, and energy were given due consideration.

\subsubsection{Water and Sanitation}

Water is essential for the survival of humanity. Due to its importance, issues concerning water and sanitation have undergone discussions at all levels of international discourse. However, as maintained by Allen, Dàvila \& Hofmann, (2006b), the urban poor are normally the most affected people when access to water and sanitation is impaired. Water usage within the household is basically for domestic purposes which include washing, bathing, cooking and drinking. Not only has access to water and sanitation been deemed important necessities for life, but more significantly, functions of housing quality (Fiadzo, 2004). Consequently, no holistic appreciation could be made of the socio-economic conditions of caretaker families living in uncompleted housing units in the Awutu-Senya East Municipality without recourse to water and sanitation. However, the field results postulate that majority (96\%) of the study population lacked access to water in the dwellings in which they resided, and hence, depended on neighbours for the supply of water. Despite the problem of distance to various sources of water in the Municipality, the average monthly cost of water ( $\mathrm{GH} \phi 65)$ was also a big problem for caretaker families residing in uncompleted housing units. The main source of water for domestic activities for majority (71 percent) of the sampled respondents was water drawn from wells, while piped-borne water constituted 23 percent, while the remaining 6 percent, used water from rivers.

The essence of sanitation in any building endeavour cannot be overemphasized, as it determines the health status of any population (Hutton and Haller, 2004)). However, a major challenge facing many developing countries undergoing rapid urbanization is the issue of sanitation and waste management (Chaplin, 1999). Consequently, giving outmost priority to access to sanitation in all facets of life has received fierce international debate. Research evidence maintains that not only is human fecal waste an important source of disease causing organisms but more seriously, it is the single most dangerous pollutant in surface water supplies (World Health Organisation and UNICEF, 2008). Additionally, inadequate sanitation is a major risk factor for diarrheal and parasitic diseases, inadequate waste collection services present a variety of hazards, (Moore, et al., (2003). However, while the research results provided that readily access to water was a major challenge for caretaker families in the study Municipality, nearly 83 percent of the sampled population did not have access to privately owned toilet facilities. Pit latrines were the most commonly used toilet facility (68 percent) among households who had access to privately owned toilet facilities, followed by KVIP (21 percent), and households with access to water closets (WCs) constituted 10 percent, as illustrated in in Figure 5. 


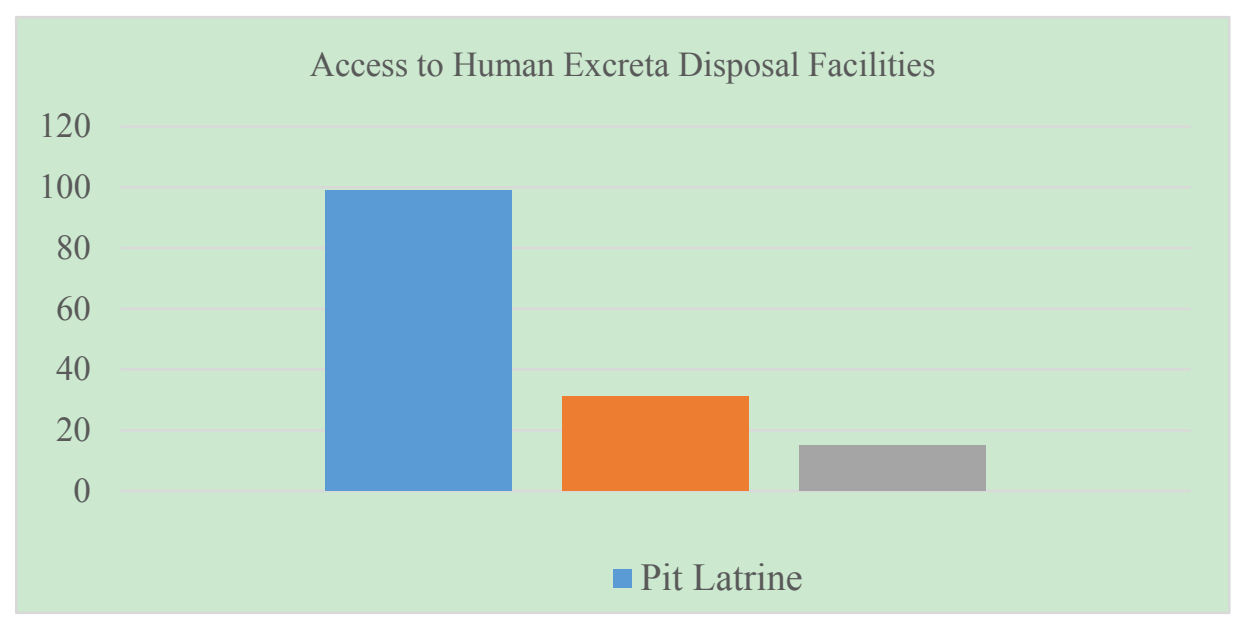

Figure 5. Access to human excreta disposal facilities

Field Survey, January 2015

Waste is bound to accumulate in any human habitation, and thus required critical steps to ensure effective and efficient handling of the wastes generated at homes if health dangers were to be forestalled (UNICEF and WHO, (2004). However, despite the fact that access to human excreta disposal facilities was virtually non-existent among caretaker families in the Awutu-Senya East Municipality, solid wastes disposal was rather precarious. Due to the inability of respondents to afford the cost of waste collection services in the Municipality, about 81 percent of the sampled respondents resorted to burning their solid wastes while 13 percent buried the refuse they generated, and 6 percent patronised waste collection services. Aside the issue of cost, it was realised that waste collection services were non-existent in most of the areas sampled, hence, compelling respondents to either burn or burry the refuse they generated. Moreover, none of the respondents residing in the uncompleted houses surveyed had proper drainage for the disposal of liquid wastes. As a result all the respondents (100 percent) disposed-off the liquid wastes they generated in the open spaces in front of the uncompleted houses they occupied. Paddles of water were therefore identified in most (96 percent) of the houses surveyed, and thus served as breeding grounds for mosquitoes aside the deteriorating environmental quality it caused.

\subsubsection{Energy}

Lightening represents one of the most important basic facilities deemed relevant in contemporary building regulation. From the field survey however, 39 percent of the respondents used battery-powered torch lights, 31 percent used kerosene to power their lamps for lighting and 8 percent of the respondents used electricity for lighting. Additionally, while less than 2 out of every 10 (18 percent) of the respondents depended on solar lumps for lighting in the Municipality, 4 percent used Candle. Undoubtedly, not only does such a situation pose danger for fire outbreaks but also, has negative consequences on the academic performance of affected children who could not learn at home because of poor lightening. The situation was underpinned by the fact that most (86 percent) of the sampled houses lacked access to electricity connections since those houses were yet to be completed. Though bemoaned the situation, respondents were however helpless as over 93 percent felt reluctant to evacuate the houses they occupied for the renting of fully completed houses which have high rental cost. (See table 2) 
Table 2. Source of energy for lightening

\begin{tabular}{lll}
\hline Energy & Frequency & Percentage (\%) \\
\hline Electricity & 12 & 8.3 \\
Battery-Powered Torch Light & 56 & 38.6 \\
Kerosene Lamps & 45 & 31.1 \\
Solar lump & 26 & 17.9 \\
Candle & 6 & 4.1 \\
Total & 145 & 100 \\
\hline
\end{tabular}

Source: Field Survey, January 2015

Access to a kitchen appeared to be virtually non-existent for the sampled respondents in the Awutu-Senya East Municipality. Consequently, about 98 percent of the caretaker families cooked either in front or at the back of the houses they occupied through the use of charcoal while 2 percent cooked at the kitchen within the house. The situation was explained from the fact that such dwelling units did not have readily available kitchens for cooking due to the fact that the dwelling units they occupied were uncompleted to allow for the use of the kitchens. Additionally, even in houses where the respondents used gas cylinders to cook at the kitchen, the kitchens were exclusively reserved to be used by the landlords upon completion of the houses in question.

\subsection{The Motivations behind the Occupation of Uncompleted Houses by Caretaker Families in the Awutu-Senya East Municipality}

For decades, literature provides that caretaker families usually seek habitation in uncompleted houses as a result of poverty, unemployment and low social class (Angel, 2000). Additionally, the difficulty in getting access to land, and housing supply constraints provide a conducive atmosphere for people to resorting to dwelling in uncompleted housing units (Duncan, 2005). From the research results however, nearly 79 percent of the sampled families maintained that low household income which made it difficult to afford a standard housing unit had been the main motivation for opting to be caretakers. On the contrary, about 14 percent asserted that ineffective government policies, and, or regulatory framework concerning housing rent in Ghana had compelled them to seek shelter in uncompleted houses in the study Municipality. This was due to the fact that aside the high cost of housing rent (with the minimum rent being GH 50.00 in most cases) in the Municipality, landlords usually require that prospective tenants pay between 3 years and 5 years 'rent advance'. In the view of 6.9 percent of the respondents, the high cost of land in the Municipality served as a barrier for low income earners to acquire lands for subsequent building residential housing as shown in figure 6 .

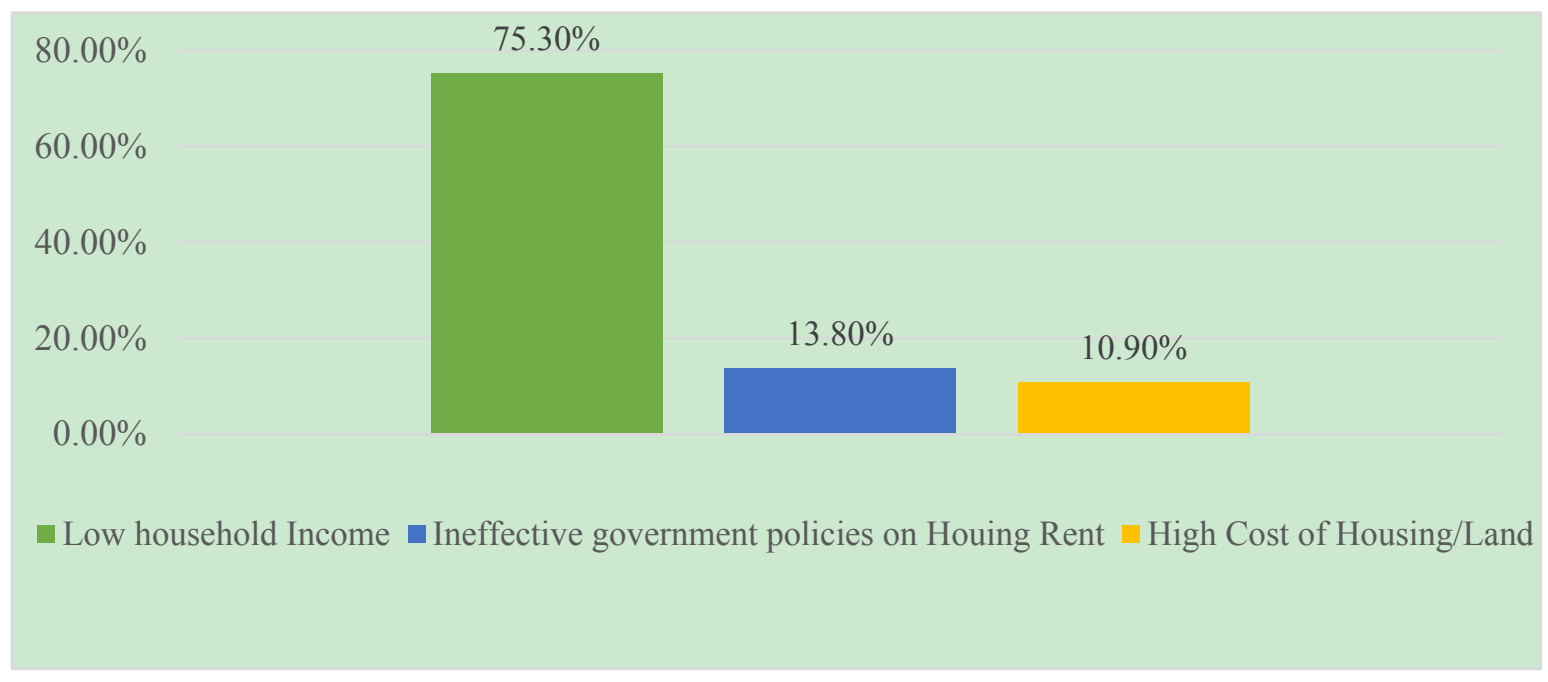

Figure 6. Motivation for the occupation of uncompleted houses in the Municipality

Sources: Field Survey, December 2014. 
From the research results in figure 6, it could be inferred that the compelling factors that influenced the choice of caretaker families to dwell in uncompleted housing units in the Awutu-Senya East Municipality were purely policy-induced under most circumstances. Though the social class in which a people find themselves (as a result of their level of education and the types of occupations engaged in, and hence their income levels) determine the types of housing units to occupy, the external compelling factors are also enormous and could not be overlooked. For instance, not only do incomprehensive government policy on housing and lack of strict enforcement of existing regulations on rent influence the choice of dwelling in uncompleted houses in the Awutu-Senya East Municipality, but also the high cost and difficulty in acquiring land for residential housing purposes. These factors, in the context of this research undoubtedly have dire influence on the choice of housing units caretaker families occupy in the Municipality. Since the income levels of majority of the sampled respondents $(88 \%)$ were below GHC 500, coupled with their low level of education, they were forced to seek shelter in uncompleted houses. Figure 6 best summarises the compelling causes of increased dwelling in uncompleted houses by caretaker families in the study Municipality.

Despite the global concern for the provision of decent but affordable housing units for citizens the world over, studies in this area maintain that the deteriorating housing affordability policies in most countries is as a result of rapid urbanization and deliberate urban containment policies of governments without due recourse to effective monitoring of housing prices in relation to households' incomes (Cox and Pavletich, 2013). In the case of Ghana however, and for that matter the Awutu-Senya East Municipality, urban containment policy could not have been the principal cause of housing deficit as governments' efforts in regulating the housing sector and its challenges have proven rather unsuccessful. The research results thus, affirmed that problem of housing challenges in Ghana is a direct attribution to rigid land acquisition procedures, weak enforcement of standards and codes in the design and construction of houses; ineffective rural housing policy; and haphazard land development; aside the issue of rapid urbanisation as espoused by the National Development Planning Commission [NDPC], 2010.

Despite the fact that incomprehensive governments' policies and ineffective enforcement of existing regulations on housing over the years compel a people to seek shelter in uncompleted houses in the study Municipality, the relationship between the type of a housing unit they occupy and their level of education cannot however be overlooked. For instance, analysis of the educational attainments of the sampled respondents revealed that the highest educational attainment level of majority (51\%) of the caretaker families was at the Junior High School level while about 35 percent had never attended school before in their lifetime. Additionally, about 7.6 percent of the sampled respondents (caretaker families living in uncompleted houses) were Senior High School leavers while 3 percent attended a vocational school, and 3.4 percent attended a primary school as depicted in figure 7 .

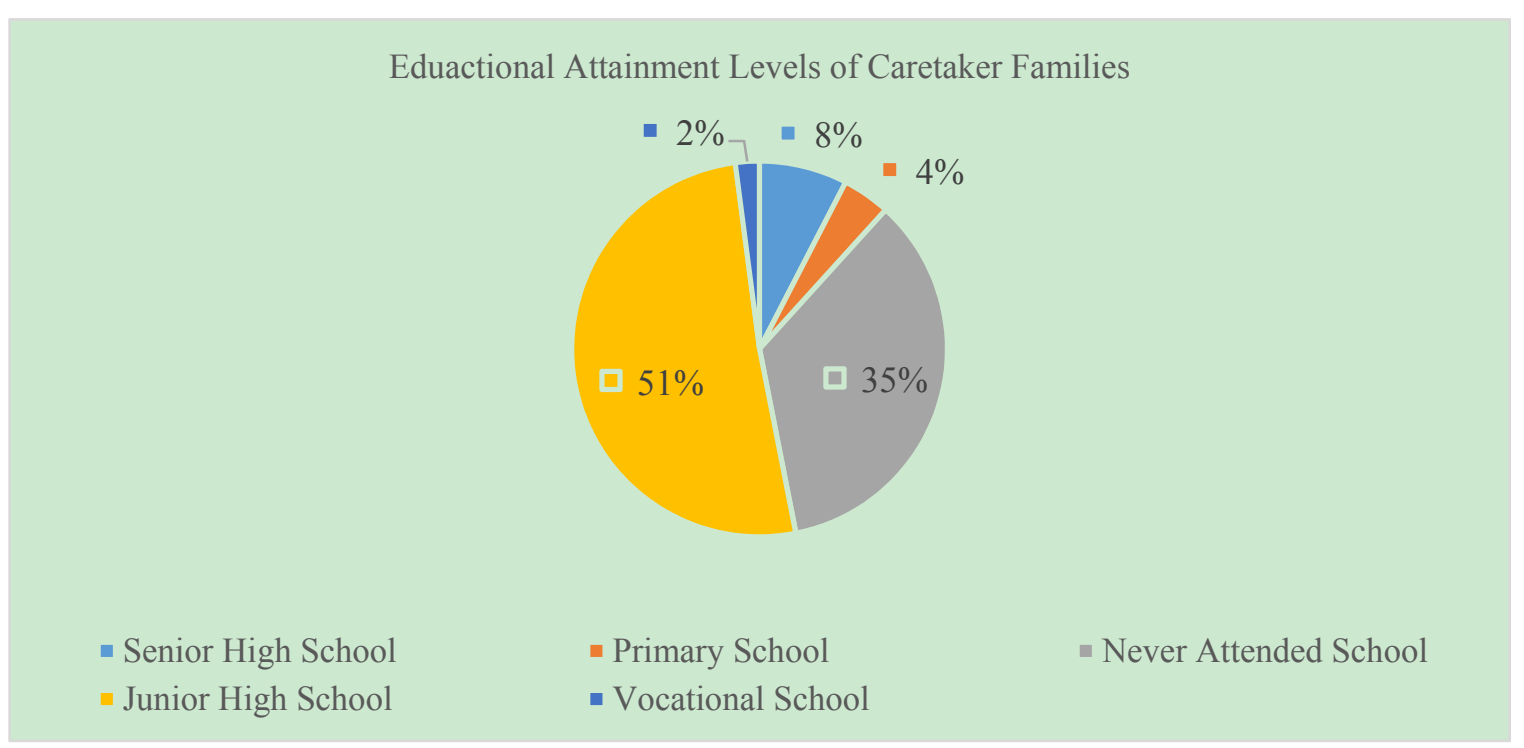

Figure 7. Educational attainment levels of caretaker families in the Awutu-Senya East Municipality

Source: Authors' Construct, January 2015 


\subsection{Challenges Encountered by Caretaker Families}

The challenges encountered by caretaker families in the study Municipality are diverse but very common among all the respondents. Principal among these challenges included poor security which made them prone to theft cases; overcrowding as a result of limited room space; poor access to facilities such as electricity due to the fact that the buildings they were occupying were uncompleted; poor access to water and decent sanitation, inter alia. For instance, 43 percent bemoaned the fact that due to poor security, their belongings were easily stolen. Moreover, due to poor lightening in various homes, children of affected families are unable to learn at home after school, a development that had serious repercussion on the school performance of such children. More serious to the problem is the difficulty most caretaker families have to go through to look for similar dwelling units when the ones they occupy are completed for habitation by owners. The situation thus exposes respondents to livelihood vulnerabilities. As advanced by Wallman (1984), the concept of livelihood goes beyond just finding or making shelter, translating money and preparing food or exchange in the market places but more importantly, it also involves the management of social relationships, the affirmation of personal significance and group identity and the interrelation of each of these tasks to the other. However, due to the inability of respondents to have a full realisation of these important elements, they are often compelled to dwell in uncompleted houses in the Municipality by going into agreements with the owners to safeguard their houses on their behalf until completion of such houses.

\section{Summary of Major Findings}

The research has revealed that the socio-economic conditions of caretaker families living in uncompleted houses in the Awutu-Senya East Municipality require the adoption of pragmatic measures to address the housing problems in Ghana as a whole. The study established that not only were caretaker families in the Municipality overcrowded due to limited habitable rooms to adequately accommodate the entire family members but also access to essential housing facilities was lacking. For instance, it was established that about 96 percent of all the study population lacked access to water in the dwellings in which they resided, and thus spent an average of GH $\phi$ 65 on water on monthly basis. Additionally, access to sanitation was identified to be very problematic resulting in nearly 83 percent of the sampled population accessing public toilet facilities in the Municipality. Regardless of the efforts of national and local level authorities to enhance citizens' access to decent toilet facilities in the country, pit latrines were identified as the most commonly used toilet facility (68.3 percent) among households who had access to privately owned toilet facilities while KVIP represented 21.4 percent. Moreover, though about 81 percent and 13 percent of the study population burn and bury their refuse respectively as methods of disposing off the solid wastes they generated, virtually all the respondents disposed-off the liquid wastes they generated in the open spaces in front of the uncompleted houses they occupied due to lack of properly constructed channels and also due to the fact that the dwelling units they occupied were substandard (uncompleted). Additionally, about 86 percent of the sampled households lacked access to electricity connections. Consequently, about 38.6 percent of the respondents used battery-powered torch lights, 31.1 percent used kerosene to power their lamps for lighting while 8.3 percent of the respondents used electricity for lighting. Additionally, while 17.9 percent of the respondents depended on solar lumps for lighting in the Municipality 4 percent used Candle, a situation that has serious recipe for fire outbreak.

Despite the serious lack of access to essential housing facilities by respondents due to the types of housing units they occupied, they felt reluctant however to evacuate the units they occupied due to a number of compelling factors. Among the factors included high cost of rental housing in the Municipality coupled with predatory nature of some landlords/ladies in housing rental agreements. Also, rigid land tenure system; ineffective enforcement of existing rental housing regulations; low monthly incomes of respondents which was directly attributable to their levels of education, and hence the types of economic activities engaged in made it extremely difficult for respondents to trade off the free housing rent they were enjoying for being caretakers.

\section{Conclusion}

Decent but affordable housing is deemed a precondition necessary for the personal growth of the individual. Despite the acknowledgement of this indisputable fact, housing deficit, high cost of building and or renting, among others are still eminent in Ghana as revealed by the study. The research has revealed the plights of caretaker families living in uncompleted houses in the Awutu-Senya East Municipality. The aim of the research was to examine the socio-economic conditions of caretaker families living in uncompleted houses in the study Municipality; the challenges they encounter in accessing essential housing facilities, among others; and to propose policy intervention measures to address the findings identified from the study. The study established that aside the poor/lack of access to essential facilities including electricity, and water and sanitation, caretaker 
families had to evacuate the houses they occupied when completed, a development that made them very vulnerable.

Despite the challenges caretaker families living in uncompleted houses in the Municipality were bedevilled with, factors such as low level of income, lack of pro-poor mortgage financing arrangements, as well as ineffective enforcement of housing regulation in the housing sector make it extremely difficult for such a situation to be minimised. Based on the outcome of the study the following recommendations are worth considering: a well-defined and comprehensive integrated system of housing finance should be instituted to enable low income earning households own decent but affordable housing. This could be done by providing alternative strategies to mortgage financing arrangement that will be pro-poor friendly for both low income and middle income earners since the implementation of the existing laws such as the Mortgages Decree of 1972 and the Home Mortgage Act, 1993 have failed to address the housing needs of the poor. Additionally, enactment of a strong and effective legal and regulatory framework for the housing sector is inevitable. The aim of this is to provide a mutual understanding for all the sector players in Ghana on the need to develop a pro poor friendly market-based housing sector. Additionally, the amendment of the Ghana's Rent Act, 1963 should be made as a matter of urgency to reflect current housing realities in Ghana. Not only has the existing Rent Act outlived its usefulness in addressing the housing needs of the poor but has also failed to provide the needed negotiation relationship between landlords/ladies and tenants. It is also important that coherent efforts are made to intensify the propagation of the importance of education since invariably a peoples levels of education influence their social class, the kinds of occupation engaged in, their income generating abilities, and thus the kinds of housing choice they make.

\section{References}

Adedeji, Y. M. D. (2004). Sustainable Housing for Low-Income Industrial Workers in Ikeja -Ilupeju Estate: Materials Initiative Options. Paper presented at the School of Environmental Technology, Federal University of Technology, Akure.

Ahadzie D. K., \& Amoah-Mensah K. (2010). Management Practices in the Ghanaian House Building Industry. Journal of Science and Technology, 30(2), 62. http://dx.doi.org/10.4314/just.v30i2.60533

Allen, A., Dàvila, J. D., \& Hofmann, P. (2006b). The Peri-Urban Water Poor:citizens or Consumers? Urbanisation and Environment , 18(2), 1-20. http://dx.doi.org/10.1177/0956247806069608

American Joint Centre for Housing Studies. (2011). Rental Housing Affordability. tabulations of US Census Bureau, American Community Surveys.

Angel, S. (2000). Housing Policy Matters: A Global Analysis. New York, Oxford University Press, USA.

Aribigbola, A. (2001). Housing and Nigerian Development: Assessment of Policy Measure and Direction. African Journal of Environmental Studies, 2(2), 117-122.

Awutu-Senya East Municipal Assembly. (2013). Draft District Medium Term Development Plan, DMTDP (2010-2013), Kasoa, ASEMA.

Badasu, D. M. (2004). Patterns of Child Care and Their Relationship with the Nutritional and Health Status of Children of Ewe Migrants in The city of Accra. Doctoral Thesis, Department of Geography and Resource Development, University of Ghana.

Bank of Ghana. (2007). The Housing Market in Ghana. Research Department, Accra, Bank of Ghana.

Chambers, R., \& Conway, G. (1992). Sustainable Rural Livelihoods: Practical concepts for the $21^{\text {st }}$ centuary. IDS Discussion Paper 296. Brighton, UK, IDS.

Chaplin, S. E. (1999). Cities, sewers and poverty: India's politics of sanitation. Environment and Urbanization, 11(1), 145-158. http://dx.doi.org/10.1177/095624789901100123

Clottey, B. (2007). A brief History of Housing in Ghana. The Statesman 9th, January, 2007.Cox, W. and Pavletich, H. (2013). 10th Annual Demographia International Housing Affordability Survey, Illinois, USA: Demographia.

DEHLG. (2010). Managing and Resolving Unfinished Housing Development. Guidance Manual, Public Consultation Draft. Department of the Environment Heritage and Local Government, Republic of Ireland.

Duncan, J. (2005). Causes of Inadequate Housing in Latin America and the Caribbean; Habitat for Humanity, Latin America and Caribbean.

Fiadzo, E. (2004). Estimating the Determinants of Housing Quality: The Case of Ghana. Cambridge, 
Massachusetts: Joint Center for Housing Studies, Harvard University.

Ghana Statistical Service. (2012). 2010 Population and Housing Census: Summary Report of Final Result. GSS, Accra, Ghana.

Ghana Statistical Service. (2002). 2000 Population and Housing Census, Summary report of Final Results. Accra, Ghana, GSS.

Ghai, D. (2002). Social security priorities and patterns: A global perspective. Geneva, Switzerland, The International Institute for Labour Studies.

Giddings, W. S. (2007). Housing challenges and opportunities in Sub-Saharan Africa. International Housing Coalition, Washington DC.

Hutton, G., \&Haller, L. (2004). Evaluation of the Costs and Benefits of Water and Sanitation Improvements at the Global Level. Geneva: World Health Organization.

Kumasi Metropolitan Assembly [KMA]. (2010). About Kumasi Metropolis. Kumasi Metropolitan Assembly, Ghana. Retrieved October 25, 2013, from http: $/ \mathrm{kma}$,ghanadistricts.gov.gh $/$ ?arrow=atd\&_ $=6 \& \mathrm{sa}=5475$

Medina M. (1998). Border Scavenging, A case study of Aluminum Recycling in Laredo Resources, Conservation and Recycling. Elsevier Science, Philadelphia.

Modupe, O. (1986). Housing Provision in a Depressed Economy. Paper presented at the then Ondo State Polytechnic, Owo, Nigeria.

Moore, M., Gould, P., \& Barbara , K. S. (2003). Globalization and Impact on Health. International Journal of Hygiene and Environmental Health, Issue Global urban health, 269-278. http://dx.doi.org/10.1078/1438-4639-00223

Ministry of Local Government and Rural Development. (2010). Environmental Sanitation Policy. Ghana, Accra.

Ministry of Water Resources, Works and Housing. (2009). Sector Medium Term Development Plan (2010-2013), Accra. Ministry of Water Resources, Works and Housing, Republic of Ghana.

National Development Planning Commission [NDPC]. (2010). Final Draft; Policy Framework: Ghana Shared Growth and Development Agenda (GSGDA 2010-2013). Accra, Ghana.

Owusu, S. E., \& Asamoah, P. K.B. (2005). Servicing Land for Housing Development in Peri-Urban Areas of Kumasi Ghana: The Theory Versus Practice. Journal of Science and Technology, 25(1), 77-85. http://dx.doi.org/10.4314/just.v25i1.32934

PACO, \& IHC. (2006). Housing for All: Essential to Economic, Social, and Civic Development, prepared for the World Urban Forum III Vancouver.

Quigley, J. M., \& Raphael, S. (2004). Is Housing Unaffordable? Why Isn't It More Affordable?. Journal of Economic Perspectives, 18(1), 191-214. http://dx.doi.org/10.1257/089533004773563494

Robert Wood Johnson Foundation. (2008). Housing and Health: Where we live Matters for Our Health: The Links between Housing and Health. Retrieved February 5, 2014, from http://www.commissiononhealth.org

Swadish Cooperative Centre [SCC]. (2005). Policy Paper on Housing and Habitat, presented in Copenhagen by Kooperation Utan Gränser/SCC.

Turner, J. (1976). Housing by People: Towards Autonomy in Building environment. London. Labyrinth Publication Ltd.

United Nations Development Programme. (2006). Human Development Report 2006. Beyond Scarcity: Power, Poverty, and the Global Water Crises. London: Palgrave Macmillan for United Nations Development Programme.

UNICEF, \& WHO. (2004). Meeting the MDG Drinking Water and Sanitation Target: A Mid-Term Assessment of Progress. Geneva, Switzerland: UNICEF/WHO.

United Nations Human Settlements Programme. (2011). Affordable Land and Housing in Africa. Vol.3. UNON, Publishing Services Section, Nairobi, Kenya.

Vuluku, G., \& Gachanja, J. (2014). Supply Side Aspects of Residential Housing for Low Income Earners in Kenya. Journal of Research in Applied Economics, 6(3), 271-284. http://dx.doi.org/10.5296/rae.v6i3.6171

Wallman, S. (1984). Eight London Households. London, Tavistock 
Wardrip, K., Williams, L., \& Hague, S. (2011). The role of affordable housing in creating Jobs and stimulating local economic development. Centre for housing policy. Retrieved from http://www.nhc.org/media/files/Housing-and-Economic-Development-Report-2011.pdf

Wilkinson, D. (1999). Poor Housing and Ill Health a Summary of Research Evidence, the Scottish Office, Central Research Unit, Scotland, UK.

Wood, J. A. (2004). Economic Impact of Affordable Housing: New Construction, Rehabilitation and Assistance Programs. Salt Lake City, UT: Utah Housing Coalition.

World Health Organisation and UNICEF. (2008). Progress on Drinking Water and Sanitation: Special Focus on Sanitation 2008. Geneva and New York:WHO Press.

\section{Copyrights}

Copyright for this article is retained by the author(s), with first publication rights granted to the journal.

This is an open-access article distributed under the terms and conditions of the Creative Commons Attribution license (http://creativecommons.org/licenses/by/3.0/). 